\title{
PENERAPAN TEOREMA BAYES UNTUK MENDIAGNOSA PENYAKIT TELINGA HIDUNG TENGGOROKAN (THT)
}

\author{
Imamah $^{1}$, Akhmad Siddiqi $^{2}$ \\ ${ }^{1,2}$ Prodi Sistem Informasi, Fakultas Teknik,Universitas Trunojoyo \\ J1. Raya Telang, PO BOX 2 Kamal, Bangkalan

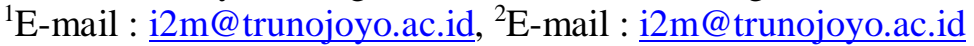

\begin{abstract}
ABSTRAK
Penyakit Telinga, Hidung dan Tenggorokan (THT) adalah penyakit yang umum diderita dan seringkali dianggap penyakit tidak berbahaya oleh masyarakat, sehingga mereka mengganggap tidak perlu ke dokter. Namun pada faktanya, penyakit THT juga dapat memberikan gangguan yang serius jika tidak segera ditangani secara dini dan tepat, sehingga dibutuhkan system pakar penyakit THT untuk melakukan deteksi dini terhadap penyakit tanpa harus berkonsutasi pada dokter, sebagai referensi awal untuk memutuskan apakah perlu ke dokter atau tidak. Berdasarkan permasalahan tersebut, pada penelitian ini diajukan penerapan teorema bayes untuk deteksi dini penyakit THT. Jenis penyakit yang digunakan pada penelitian ini sebanyak enam jenis, dan memiliki 22 gejala. Pengguna melakukan input gejala yang dialami pada system, kemudian system akan memberikan hasil diagnosa. Hasil diagnosa ini dapat digunakan sebagai rujukan awal bagi penderita dan dapat digunakan sebagai referensi bagi para dokter muda yang sedang menempuh pendidikan kedokteran dengan bidang spesialis THT. Pada penelitian tahap awal ini, pengujian dilakukan untuk menghitung waktu komputasi yang dibutuhkan oleh system untuk mendiagnosa penyakit THT. Berdasarkan uji coba yang telah dilakukan waktu komputasi rata-rata yang dibutuhkan system untuk melakukan diagnose adalah 00:09:54 atau Sembilan menit, lima puluh empat detik.
\end{abstract}

Kata kunci : Penyakit THT, Teorema Bayes, system pakar, waktu komputasi.

\section{ABSTRACT}

Ear, Nose and Throat Disease (ENT) is a common disease that is often considered a harmless disease by people, so they assume there is no need to see a doctor. But in fact, ENT disease can also provide serious disorders if not treated early and right, so the expert system of ENT is needed for early detection before the patient decided to see a doctor or not. Based on these problems, this study proposed the application of the Bayes theorem for early detection of ENT disease. The types of diseases used in this study were six types and had 22 symptoms. User inputs the symptoms of a disease, then the system will provide a diagnosis. This diagnosis can be used as an initial reference for sufferers and can be used as a reference for young doctors who are taking medical education with an ENT specialist. In this initial research, testing was carried out to calculate the computational time needed by the system to diagnose ENT disease. Based on this research, we found that the average computing time needed by the system to diagnose is 00:09:54 or Nine minutes, fifty-four seconds.

Keyword : Ear, Nose and Throat disease, Bayes theorem, expert systems, computational time.

\section{PENDAHULUAN}

Telinga, hidung, dan tenggorokan (THT) adalah organ tubuh yang sangat vital bagi manusia. Hal ini disebabkan karena THT berkaitan dengan system pendengaran dan pernafasan pada manusia. THT dihubungkan melalui saluran Eustachian tube, yang menyebabkan gangguan pada salah satu organ THT akan saling berpengaruh. Penyakit THT dari kasus terbanyak berasal dari infeksi bakteri dan virus. Berdasarkan data dari RSUD Raden
Mattaher Jambi diketahui bahwa pada tahun 2010 ditemukan sebanyak 978 pasien menderita tonsillitis kronis dari 1365 jumlah kunjungan, sedangkan pada tahun 2011, ditemukan sebanyak 789 pasien dari total 1144 jumlah kunjungan[1]. Data ini menunjukkan tingginya jumlah pengguna THT, hal yang menjadi pertanyaan adalah apakah jumlah pengguna dan jumlah pakar atau dokter spesialis THT di setiap daerah cukup memadai atau tidak. Jika jumlah pakar telah memadai, namun dengan tingginya jumlah 
pengguna maka tentu akan meningkatkan waktu atrian pada tiap rumah sakit, sehingga menimbulkan rasa enggan untuk berobat ke rumah sakit. Apalagi penyakit THT oleh sebagian besar masyarakat dianggap sebagai penyakit ringan dan tidak perlu berobat ke dokter[2]. Padahal menurut data penelitian Savitri, jumlah pengguna penyakit THT menempati peringkat kedua penyakit di Indonesia[1].

Untuk mencegah meningkatnya jumlah pengguna penyakit THT, maka pada penelitian ini diajukan system pakar untuk deteksi dini penyakit THT menggunakan teorema bayes. sistem pakar adalah proses adopsi pengetahuan manusia ke computer, dengan tujuan komputer dapat memiliki kepakaran manusia dan menyelesaikan masalah layaknya seorang pakar[3][4][5][6]. Dengan adanya system pakar ini diharapkan masyarakat dapat melakukan deteksi dini penyakit THT untuk mencegah infeksi berlanjut dan menjadi kronis, namun bukan berarti system ini nantinya akan meniadakan peran dokter spesialis, tetapi system ini dapat dijadikan rujukan awal baik bagi pengguna maupun bagi dokter muda.

\section{METODOLOGI}

Tahapan dalam penelitian ini meliputi beberapa proses yang ditunjukan pada gambar 1 .

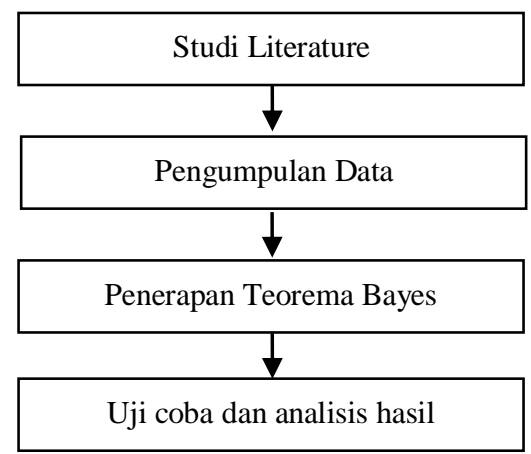

Gambar 1. Metode Penelitian

Penjelasan secara terperinci mengenai tahapantahapan penelitian dijelaskan berikut ini:

\section{Studi Literature}

Pada tahapan ini dikumpulkan teori yang berkaitan dengan penelitian yaitu mengenai penyakit THT dan Teorema bayes.

\section{a. Penyakit THT}

Kelainan pada organ telinga, hidung dan tenggorokan akan saling menyebar. Hal ini dikarenakan adanya saluran eustachian tube yang menghubungkan ketiga organ tersebut[7]. Oleh karena itu, penyakit yang menyerang salah satu organ tersebut, diperiksa secara keseluruhan pada ketiga organ dan dilakukan oleh dokter spesialis THT.

Telinga terdiri dari telinga luar yang berfungsi untuk menangkap gelombang, telinga tengah berfungsi sebagai pengubah dari energi mekanis menjadi suatu gelombang yang disebut sebagai gelombang saraf yang akan diantarkan ke organ vital manusia yaitu otak, sedangkan telinga dalam berperan untuk menjaga keseimbangan pada tubuh manusia [8] .

Hidung adalah organ yang merupakan jalan masuk dan keluarnya udara dari dan ke paruparu, selain itu hidung juga berfungsi sebagai organ penciuman dan merupakan muara dari saluran air mata dan sinus paranasalis [8].

Tenggorokan yang letaknya di belakang mulut dan di atas kerongkongan adalah saluran bagi makanan menuju ke kerongkongan dan tempat jalannya udara ke paru-paru. [8].

Ada enam jenis penyakit THT yang diteliti dalam artikel ini, yaitu:

1. Otitis Media Serosa Akut.

Penyakit ini merupakan peradangan sebagian kecil atau bahkan keseluruhan dari mukosa telinga tengah.

2. Polip Hidung

Penyakit ini terjadi karena membesarnya ukuran polip, sehingga menyebabkan gangguan pada sinus.

3. Faringitis Akut Penyakit ini merupakan peradangan pada tenggorok atau hulu tenggorokan.

4. Infeksi Leher Dalam

Penyakit ini terjadi karena adanya infeksi pada ruang yang terletak diantara fasia leher.

5. Abses Retrofaring

Penyakit ini terjadi karena berkumpulnya nanah di retrofiring.

6. Karsinoma Nafosaring

Penyakit ini merupakan jenis kanker di area nasofaring.

\section{b. Teorema Bayes}

Teorema bayes adalah metode untuk menghitung ketidakpastian pada suatu data menjadi data pasti berdasarkan perbandingan data yang bernilai true (benar) dengan data yang bernilai false(salah). Probabilitas bayes 
digunakan untuk menyelesaikan permasalahan ketidakpastian data berdasarkan formula bayes yang dinyatakan sebagai berikut:

$\mathrm{P}(\mathrm{H} \mid \mathrm{X})=\frac{P(H \mid X) \cdot P(H)}{P(X)}$

Keterangan :

$\mathrm{X} \quad$ :Data yang belum diketahui kelasnya.

$\mathrm{H} \quad$ :Hipotesis data $\mathrm{X}$ dari suatu kelas

$\mathrm{P}(\mathrm{H} \mid \mathrm{X})$ :Probabilitas hipotesis $\mathrm{H}$ pada kondisi X (posteriori probability)

$\mathrm{P}(\mathrm{H}) \quad$ :Probabilitas hipotesis $\mathrm{H}$ (prior probability)

$\mathrm{P}(\mathrm{X} \mid \mathrm{H})$ : Probabilitas $\mathrm{X}$ pada kondisi hipotesis $\mathrm{H}$

$\mathrm{P}(\mathrm{X}) \quad$ : Probabilitas $\mathrm{X}$

Teorema Bayes dikenal sebagai metode yang tepat digunakan dalam permasalahan machine learning yang membutuhkan data training, dan menjadikan probabilitas bersyarat sebagai acuan dasar perhitungannya. Teorema Bayes ini juga merupakan sebuah algoritma atau metode yang dapat memberikan nilai estimasi berupa parameter yang didapatkan melalui penggabungan informasi dari data sampel dengan informasi dari data lain yang telah tersimpan sebelumnya. Salah satu alasan yang dijadikan justifikasi dalam pemilihan metode teorema bayes dalam penelitian ini adalah karena keunggulan metode teorema bayes dalam melakukan penyederhaan terhadap cara klasik yang cukup rumit menjadi model marginal yang lebih sederhana dalam perhitungannya [9].

\section{Pengumpulan Data}

Proses pengambilan kesimpulan dalam penelitian ini didapatkan dengan cara menghubungkan antara fakta dan pengetahuan mengenai penyakit THT yang telah dimodelkan dalam rules based. Fakta dan pengetahuan akan di terjemahkan oleh pembuat sistem menjadi knowledge based yang disimpan dalam database dan akan digunakan oleh system dalam proses pengambilan kesimpulan diagnosa. Knowledge based atau basis pengetahuan yang digunakan dalam penelitian ini meliputi jenis penyakit, gejala penyakit dan relasi antara gejala dan penyakit THT. Secara lebih detail, Jenis penyakit THT yang didapatkan sebagai basis pengetahuan dalam penelitian ini ditunjukan pada tabel 1 .

\begin{tabular}{cl}
\hline \hline Kode & \multicolumn{1}{c}{ Jenis Penyakit } \\
\hline P01 & Otitis Media Serosa \\
P02 & Polip Hidung \\
P03 & Faringitis Akut \\
P04 & Infeksi Leher Dalam \\
P05 & Abses Retrofaring \\
P06 & Karsinoma Nafosaring \\
\hline \hline
\end{tabular}

Pada tabel 1 , ada enam jenis penyakit THT yang diteliti, yaitu Otitis Media Serosa, Abses Retrofaring , Infeksi Leher Dalam, Faringitis Akut, Polip Hidung, dan Karsinoma Nafosaring. Dari keenam penyakit tersebut memiliki 22 gejala yang menjadi penanda dari penyakit yang dialami penderita. Gejala-gejala dari tiap jenis penyakit tersebut ditunjukan pada tabel 2 .

Tabel 2. Data gejala penyakit

\begin{tabular}{cl}
\hline \hline $\begin{array}{c}\text { Kode } \\
\text { gejala }\end{array}$ & Nama gejala \\
\hline G01 & Sakit Telinga \\
G02 & Telinga Berdengung \\
G03 & Pendengaran Menurun \\
G04 & Telinga Tersumbat \\
G05 & Demam \\
& \\
G06 & Hidung Buntu \\
G07 & Hidung Berair \\
G08 & Pilek Menahun \\
G09 & Penciuman Berkurang \\
G010 & Sakit Kepala \\
G011 & Bersin \\
G012 & Nyeri Waktu Menelan \\
G013 & Badan Panas/Meriang \\
G014 & Tenggorokan Kering \\
G015 & Mual \\
G016 & Leher Bengkak \\
G017 & Sesak Nafas \\
G018 & Nyeri Leher \\
G019 & Sulit Buka Mulut \\
G020 & Nyeri Tenggorokan \\
G021 & Ingus Darah \\
G022 & Mata Juling \\
\hline \hline
\end{tabular}

Tabel 3. Data relasi gejala dan penyakit 


\begin{tabular}{cll}
\hline Kode & Jenis Penyakit & \multicolumn{1}{c}{$\begin{array}{c}\text { Gejala } \\
\text { Penyakit }\end{array}$} \\
\hline P01 & Otitis Media & G01,G02,G0 \\
& Serosa & $3, \mathrm{G} 04, \mathrm{G} 05$ \\
P02 & Polip Hidung & G06,G07,G0 \\
& & $8, \mathrm{G} 09, \mathrm{G} 010$, \\
& & G011, \\
P03 & Faringitis Akut & G012,G013, \\
& & G014,G015 \\
P04 & Infeksi Leher & G013,G016, \\
& Dalam & G017,G018, \\
& & G019 \\
P05 & Abses & G012,G013, \\
& Retrofaring & G017,G019, \\
& & G020 \\
P06 & Karsinoma & G03,G06, \\
& Nafosaring & G010,G016, \\
& & G017,G021, \\
& & G022 \\
\hline
\end{tabular}

\section{Penerapan Teorema Bayes}

Dengan menggunakan teorema bayes, maka dapat disimulasikan jika pengguna memberi jawaban benar pada G01,G02,G03,G04,G05 misalnya, maka proses perhitungan-nya menjadi sebagai berikut:

Berdasarkan representasi penge-tahuan untuk mendiagnosis penyakit THT sesuai tabel 3, maka dapat disimpulkan jika G01 =benar, maka nilai probabilitasnya 0.8 . Jika G01 = Tidak, maka Nilai Probabilitas $=0$.

Misal Andi akan melakukan uji coba sistem, dan jawaban yang dberikan Andi tentang gejala penyakit THT yang dialami adalah sebagai berikut:

$$
\begin{aligned}
\mathrm{G} 01 & =0,8=\mathrm{P}(\mathrm{E} \mid \mathrm{H} 1) \\
\mathrm{G} 02 & =0,5=\mathrm{P}(\mathrm{E} \mid \mathrm{H} 2) \\
\mathrm{G} 03 & =0,5=\mathrm{P}(\mathrm{E} \mid \mathrm{H} 3) \\
\mathrm{G} 04 & =0,8=\mathrm{P}(\mathrm{E} \mid \mathrm{H} 4) \\
\mathrm{G} 05 & =0,6=\mathrm{P}(\mathrm{E} \mid \mathrm{H} 5)
\end{aligned}
$$

Kemudian mencari nilai semesta dengan menjumlahkan dari hipotesa di atas:

$$
\begin{aligned}
& =\mathrm{G} 01+\mathrm{G} 02+\mathrm{G} 03+\mathrm{G} 04+\mathrm{G} 05 \\
& =0,8+0,5+0,5+0,8+0,6 \\
& =3.2
\end{aligned}
$$

Setelah hasil penjumlahan di atas diketahui, maka didapatlah rumus untuk menghitung nilai semesta adalah sebagai berikut:

$$
\mathrm{P}(\mathrm{H} 1)=0.8 / 3.2=0.25
$$

$$
\begin{aligned}
& \mathrm{P}(\mathrm{H} 2)=0.5 / 3.2=0.16 \\
& \mathrm{P}(\mathrm{H} 3)=0.5 / 3.2=0.16 \\
& \mathrm{P}(\mathrm{H} 4)=0.8 / 3.2=0.25 \\
& \mathrm{P}(\mathrm{H} 5)=0.6 / 3.2=0.19
\end{aligned}
$$

Jika nilai $\mathrm{P}(\mathrm{Hi})$ telah diketahui, maka langkah selanjutnya adalah menentukan nilai probabilitas hipotesis $\mathrm{H}$ tanpa memandang evidence apapun: $=\mathrm{P}(\mathrm{H} 1) *(\mathrm{P}(\mathrm{E} \mid \mathrm{H} 1)+\mathrm{P}(\mathrm{H} 2)$ * $(\mathrm{P}(\mathrm{E} \mid \mathrm{H} 2)+\mathrm{P}(\mathrm{H} 3)$ * $(\mathrm{P}(\mathrm{E} \mid \mathrm{H} 3)+\mathrm{P}(\mathrm{H} 4) *(\mathrm{P}(\mathrm{E} \mid \mathrm{H} 4)+\mathrm{P}(\mathrm{H} 5) *(\mathrm{P}(\mathrm{E} \mid \mathrm{H} 5)$ $=(0.8 * 0.25)+(0.5 * 0.16)+(0.5 * 0.16)+(0.8 * 0.25)+($ $0.6 * 0.19)$

$=0.674$

Selanjutnya hitung nilai $\mathrm{P}(\mathrm{Hi} \mid \mathrm{E})$ atau probabilitas hipotesis $\mathrm{Hi}$ bernilai benar jika diberikan evidence $\mathrm{E}$.

$$
\begin{aligned}
& \mathrm{P}(\mathrm{H} 1 \mid \mathrm{E})=\left(0.8^{*} 0.25\right) / 0.674=0.297 \\
& \mathrm{P}(\mathrm{H} 2 \mid \mathrm{E})=(0.5 * 0.16) / 0.674=0.119 \\
& \mathrm{P}(\mathrm{H} 3 \mid \mathrm{E})=\left(0.5^{*} 0.16\right) / 0.674=0.119 \\
& \mathrm{P}(\mathrm{H} 4 \mid \mathrm{E})=\left(0.8^{*} 0.25\right) / 0.674=0.297 \\
& \mathrm{P}(\mathrm{H} 5 \mid \mathrm{E})=\left(0.6^{*} 0.19\right) / 0.674=0.169
\end{aligned}
$$

Maka prosentase Andi terkena Otitis Media Serosa (P1) adalah:

$=(0.8 * 0.297)+(0.5 * 0.119)+(0.5 * 0.119)+(0.8 * 0.2$

$97)+(0.6 * 0.169)$

$=0.695 * 10 \%$

$=69.5 \%$

Sehingga dapat disimpulkan bahwa Andi terdiagnosa menderita penyakit THT jenis Otitis Media Serosa dengan nilai probabilitas $69.5 \%$.

\section{Uji Coba dan Analisis Hasil}

Uji coba dilakukan dengan menginputkan gejala-gejala sesuai dengan rule dengan tujuan untuk mengetahui waktu komputasi yang dibutuhkan oleh system pakar, dalam mendeteksi penyakit THT.

\section{HASIL DAN PEMBAHASAN}

Metode pengembangan system pakar deteksi dini penyakit THT ini menggunakan metode Waterfall atau disebut siklus hidup klasik. Metode ini berupa pendekatan sistematis yang dimulai dari tahapan untuk melakukan spesifikasi kebutuhan, tahap kedua adalah perencanaan, tahap ketiga adalah pemodelan, tahap keempat adalah konstruksi, tahap kelima adalah deployment dan tahap terakhir adalah 
pemberian dukungan pada perangkat lunak yang dihasilkan[10]. System pakar dikembangkan berbasis web untuk memudahkan akses dari smartphone ataupun dari notebook tanpa terikat pada satu system operasi.

Gambaran dari system pakar dengan menggunakan domain model adalah sebagai berikut:

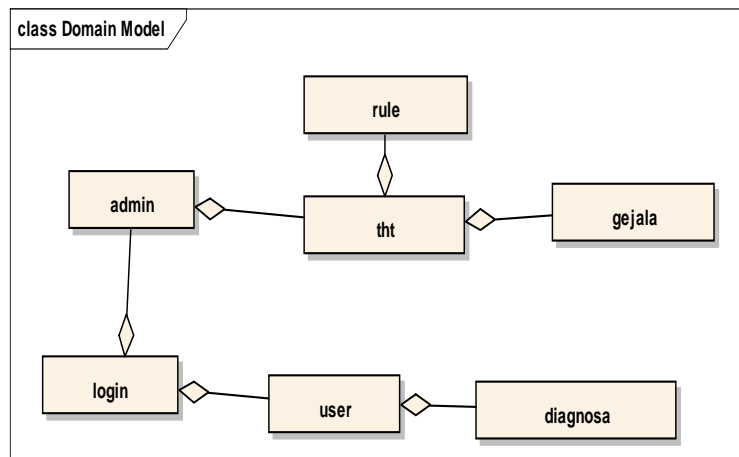

Gambar 2. Domain Model system pakar

Pada gambar 2, dijelaskan bahwa pengguna terdiri dari admin dan pengguna biasa. Pada saat admin berada pada halaman utama login, sistem akan meminta admin untuk melakukan input nama pengguna(username) dan kata sandi (password), selanjutnya data akan dicocokan dengan data pada database, jika sesuai maka sistem akan menampilkan halaman admin. Admin dapat melakukan terhadap system pakar, diantaranya yaitu memasukan rule, mengedit rule, menambahkan gejala dan lain-lain sebagaimana ditunjukkan pada n gambar 2 .

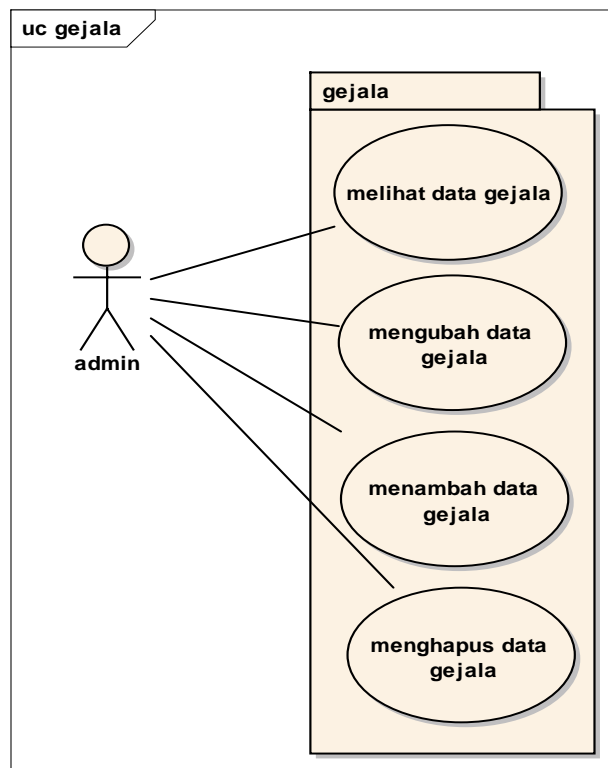

Gambar 2. Use case diagram Admin
Sedangkan pengguna bias hanya dapat memasukan gejala untuk didiagnosa oleh system dan dapat melihat hasil diagnose.secara terpisah ditunjukan gambar 3.

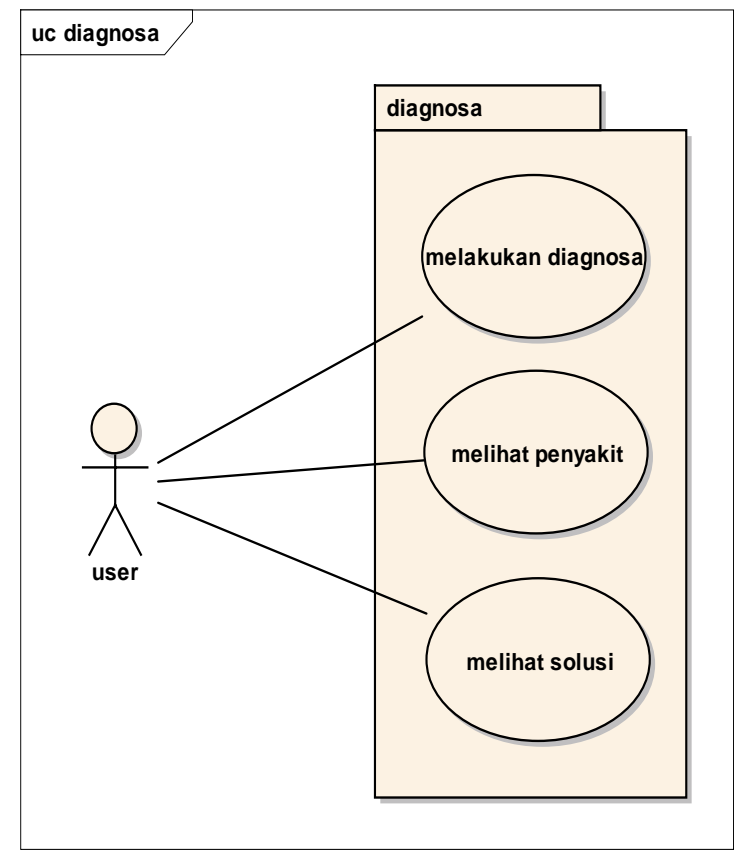

Gambar 3. Use case diagram user.

Setelah tahapan desain, pada tahap Implementasi digunakan Bahasa pemrograman PHP versi 7 , dan web server menggunakan Apache. Pada penelitian ini, system pakar dihosting pada localhost. Adapun tampilan dari system pakar ditunjukkan pada gambar 5 .

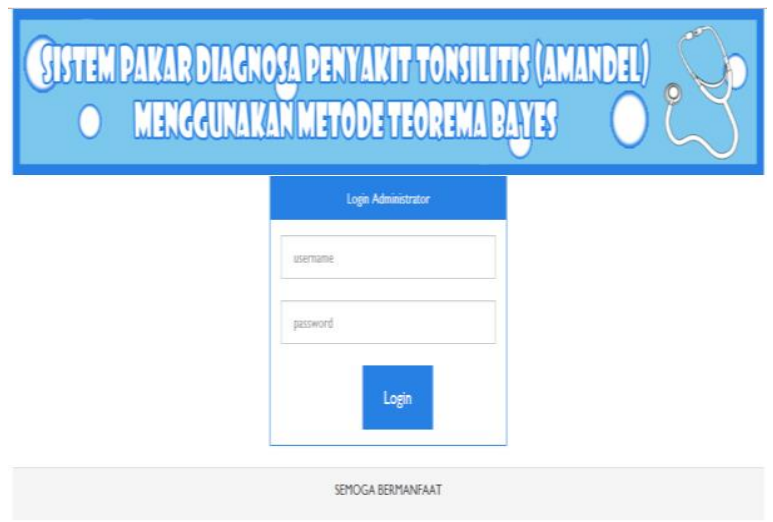

Gambar 5. Halaman Login

Pada halaman ini, pengguna akan diminta untuk melakukan input username dan password. Bagi pengguna yang belum memiliki akun dapat melakukan pendaftaran. Tujuan dari halaman login ini adalah, bagi admin agar dapat mengakses halaman dashboard untuk melakukan perubahan terhadap data penyakit, gejala dan rule 
penyakit THT. Sedangkan bagi pengguna, halaman login ini bertujuan sebagai rekapan bagi admin mengenai siapa saja yang telah melakukan uji coba sistem pakar ini.

a. Tampilan Halaman Admin

Pada halaman ini, admin memiliki otoritas untuk melakukan perubahan terhadap gejala, rule dan jenis penyakit. Sistem pakar ini dibuat dinamis, dengan tujuan memudahkan pengembangan sistem. Jika terdapat perubahan data gejala, jenis atau rule penyakit THT, admin dapat dengan mudah menambahkan ke dalam sistem. Pada gambar 6. ditunjukkan gambar untuk melakukan perubahan gejala penyakit THT.
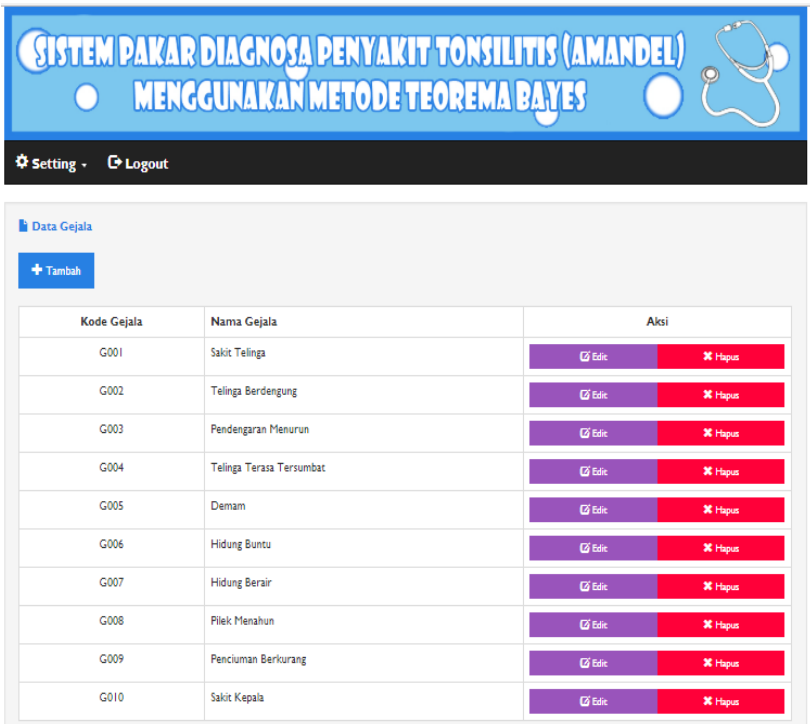

Gambar 6. Halaman admin untuk merubah gejala penyakit THT.

Halaman selanjutnya yang hanya dapat diakses oleh Admin adalah halaman untuk merubah data penyakit seperti ditunjukkan pada gambar 7 .
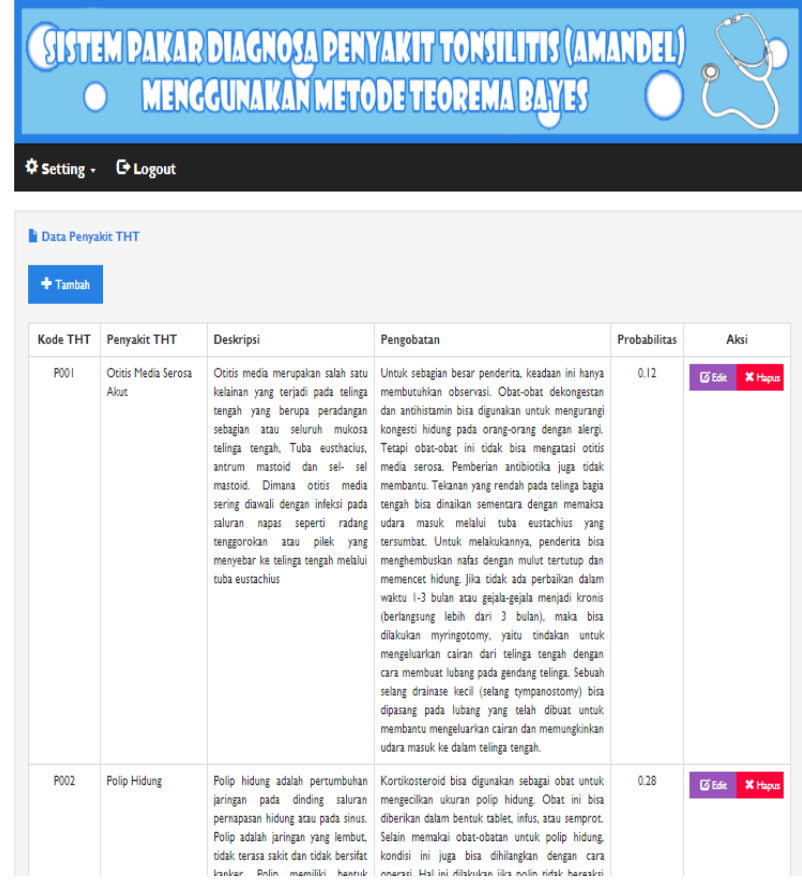

Gambar 7. Halaman admin untuk merubah data penyakit.

Pada halaman ini, admin dapat melakukan perubahan data penyakit THT. Admin dapat menambah atau mengurangi data penyakit dengan mengisi field jenis THT, deskripsi, pengobatan, dan probabilitas yang kemudian tersimpan dalam data base. Selain kedua hal ini, admin juga dapat melakukan perubahan pada data rule seperti ditunjukkan pada gambar 8 .
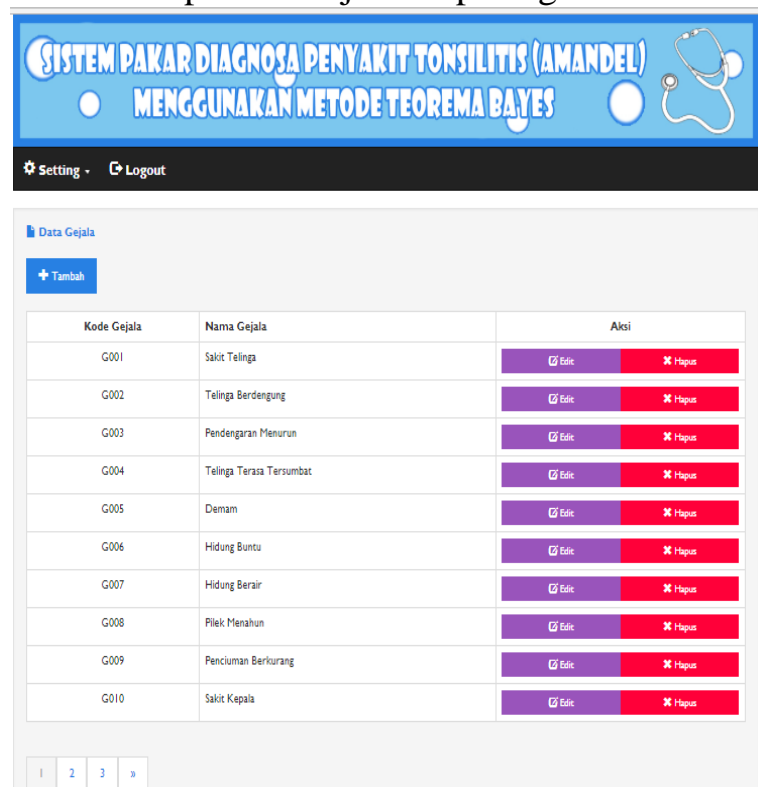

Gambar 8. Halaman admin untuk merubah data Rule. 
Pada gambar 8, admin dapat menambahkan rule penyakit THT, yaitu dengan memilih penyakit dan memilih gejala serta mengisi bobot tiap gejala yang nantinya digunakan untuk penilaian atau probabilitas dari penyakit yang diderita.

\section{b. Tampilan Pengguna}

Setelah pengguna melakukan login seperti pada gambar 5, sistem akan melakukan pengecekan apakah username dan password sudah terdaftar atau belum, jika sudah akan dilakukan pegecekan apakah level pengguna sebagai admin atau user, jika sebagai user maka pengguna akan dibawa pada halaman yang ditunjukkan pada gambar 9 .
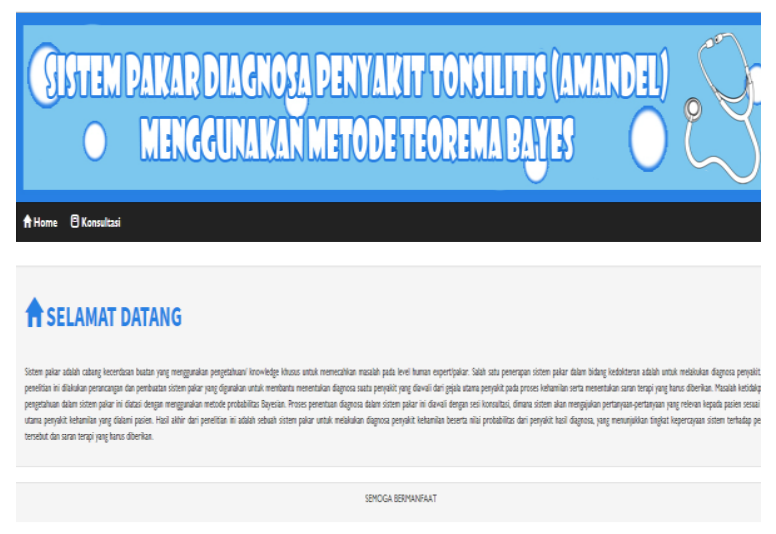

Gambar 9. Tampilan awal system pakar

Selanjutnya, pengguna akan diminta menginputkan gelaja pada halaman konsultasi seperti tampilan gambar 10 .
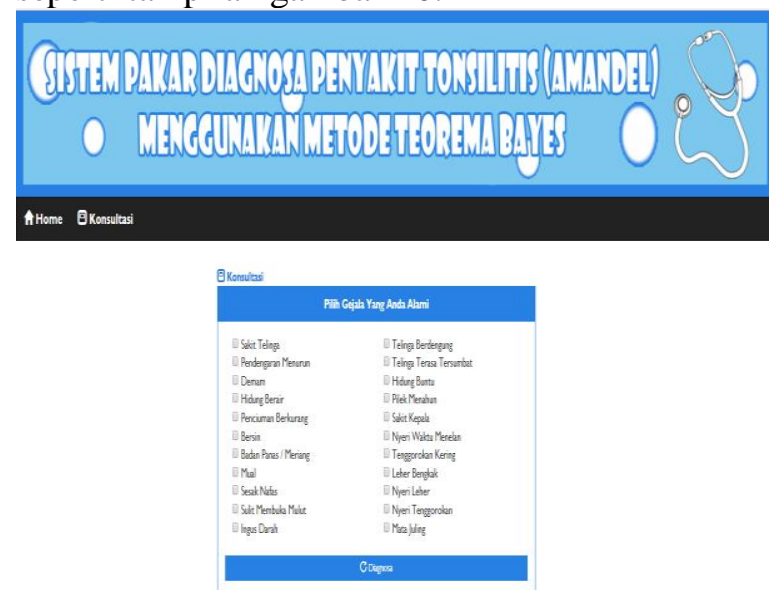

Gambar 10. Halaman konsultasi.

Pada halaman konsultasi ini, pengguna diminta memilih gejala yang dialami. Gejala dibuat dengan menggunakan checkbox, yang merupakan salah satu fitur inputan pada HTML yang memungkinkan pengguna memasukkan lebih dari satu nilai. Sebagaimana telah dikemukakan pada tabel 2, satu jenis penyakit dapat memiliki lebih dari satu gejala, sehingga system di desain untuk dapat menerima beberapa gejala dalam satu kali diagnose. Inputan gejala dari pengguna kemudian akan didiagnosa menggunakan pohon keputusan pada tabel 3. Jika pengguna misalnya menginputkan gejala G01,G02,G03, G04,G05 maka akan dilakukan proses perhitungan menggunakan naïve bayes seperti contoh diatas. Sedangkan hasil dari diagnose akan ditampilkan pada halaman diagnose seperti gambar 11 .
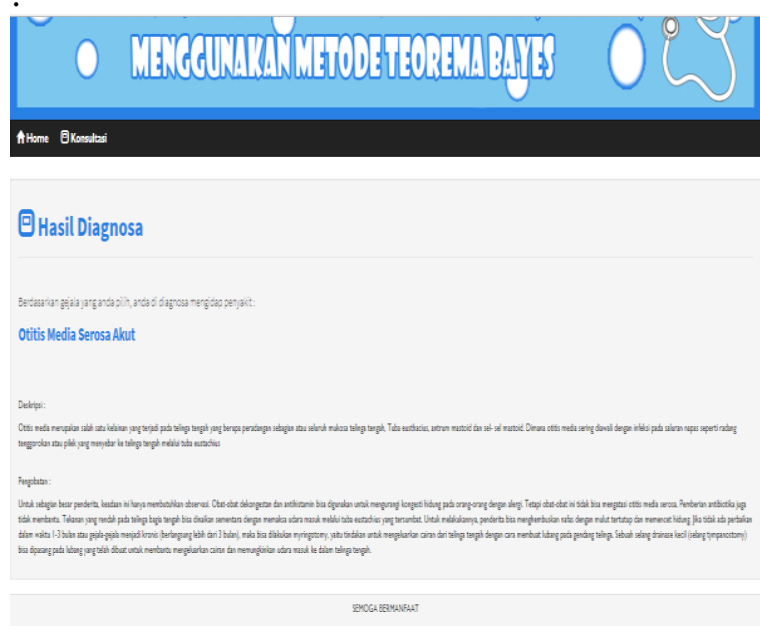

Gambar 7. Hasil diagnosa

Pada penelitian ini dilakukan uji coba untuk mengetahui waktu komputasi yang dibutuhkan system dalam mendiagnosa penyakit THT. Uji coba dilakukan dengan memasukkan gejala pada system, selanjutnya dengan menggunakan listing program sebagai berikut:

\$awal $=$ microtime $($ true $)$

//fungsi perhitungan teorema bayes

\$akhir = microtime (true);

\$lama $=$ \$akhir - \$awal;

echo "Lama eksekusi script adalah: ".\$lama." microsecond";

variabel \$awal diletakkan di awal listing program diagnosa menggunakan teorema bayes, tujuannya agar sistem mencatat waktu awal dari proses perhitungan metode. Sedangkan variable \$akhir diletakkan di akhir listing program perhitungan teorema bayes atau setelah fungsi untuk menampilkan hasil diagnosa. Tujuan dari fungsi ini untuk mengetahui lama proses komputasi metode untuk mendiagnosa penyakit THT. 
Berdasarkan gejala-gejala penyakit yang telah diinputkan oleh pengguna. Setelah waktu awal komputasi dan waktu akhir komputasi metode diketahui, maka waktu komputasi dari metode didapatkan dengan melakukan pengurangan terhadap waktu akhir dengan waktu awal, dengan demikian hasil perhitungan waktu komputasi dapat diketahui.

Dengan menggunakan cara ini, maka hasil yang didapatkan dipastikan lebih akurat dan tidak perlu dilakukan pencatatan waktu secara manual. Berdasarkan hasil uji coba yang dilakukan, maka didapatkan hasil sebagai berikut:

Tabel 4. Waktu Diagnosa

\begin{tabular}{clc}
\hline Percobaan & \multicolumn{1}{c}{ Input Gejala } & $\begin{array}{c}\text { Waktu } \\
\text { Diagnosa } \\
\text { (menit) }\end{array}$ \\
\hline 1 & G01,G02,G03,G04,G05 & $00: 05: 00$ \\
2 & G06,G07,G08,G09,G010, & $00: 09: 05$ \\
& G011 & \\
3 & G012,G013,G014,G015 & $00: 05: 40$ \\
4 & G013,G016,G017,G018, & $00: 07: 20$ \\
& G019 & \\
5 & G012,G013,G017,G019, & $00: 08: 02$ \\
& G020 & $00: 11: 02$ \\
6 & G03,G06,G010,G016, & \\
\hline Rata-rata & G017,G021,G022 & $\mathbf{0 0 : 0 9 : 5 4}$ \\
\hline
\end{tabular}

Berdasarkan uji coba yang telah dilakukan waktu komputasi rata-rata yang dibutuhkan system untuk melakukan diagnose adalah 00:09:54 atau Sembilan menit, lima puluh empat detik.

\section{SIMPULAN DAN SARAN}

Berdasarkan penelitian ini, disimpulkan bahwa semakin komplek gejala yang diinputkan oleh pengguna, maka waktu komputasi yang dibutuhkan untuk mengenali penyakit akan semakin lama. Pada saat pengguna memasukan gejala sebanyak kurang lebih lima gejala, waktu komputasi yang dibutuhkan berkisar lima menit sampai dengan delapan menit. Waktu komputasi terlama didapatkan pada saat gejala yang diinputkan oleh pengguna berjumlah tujuh gejala, dengan waktu komputasi kurang lebih sebelas menit.

Pada penelitian ini, hanya diteliti mengenai waktu komputasi dan belum diuji mengenai akurasi metode. Pada penelitian selanjutnya perlu dilakukan uji coba untuk menguji akurasi teorema bayes untuk mendiagnosa penyakit THT.

\section{REFERENSI}

[1] S. V., "Karakteristik penderita tonsilitis kronis yang diindikasikan tonsilektomi Di RSUD Raden Mattaher Jambi," Skripsi, 2013.

[2] N. K. Pebriyanti and A. W. Andika, "Sistem Pakar Penentuan Tanaman Obat pada Penyakit THT berbasis Web," SINTECH (Science Inf. Technol. J., vol. 1, no. 1, pp. 34-40, 2018.

[3] Y. R. Nasution and Khairuna, "Sistem pakar deteksi awal penyakit tuberkulosis dengan metode bayes," Klorofil, vol. 1, no. 1, pp. 17-23, 2017.

[4] R. Ramadhan, "Pemodelan Sistem Pakar Diagnosa Penyakit Tanaman Cabai Merah Dengan Metode Fuzzy-Ahp.," Repos. J. Mhs. PTIIK UB., vol. 6, no. 7, 2015.

[5] Hamdani, "Sistem Pakar Untuk Diagnosa Penyakit Pada Manusia," J. Inform. Mulawarman, vol. 5, no. 2, pp. 13-21., 2010.

[6] M. A. Fahmy, I. P. Ningrum, and J. Y. Sari, "Sistem pakar diagnosis penyakit hewan sapi dengan metode forward chaining," no. December, 2018.

[7] Y. Hendriana, "PROGRAM BANTU IDENTIFIKASI PENYAKIT THT," in Simposium Nasional Teknologi Terapan (SNTT), 2013, pp. 58-63.

[8] S. Wahyu, P., Muhammad A.W. dan Bagus, "Sistem pakar berbasis web untuk diagnosa awal penyakit THT," in Prosiding SNATI Yogyakarta, 2008.

[9] H. T. Sihotang, E. Panggabean, and H. Zebua, "Sistem Pakar Mendiagnosa Penyakit Herpes Zoster Dengan Menggunakan Metode Teorema Bayes,"' J. Inform. Pelita Nusant., vol. 3, no. 1, pp. 33-40, 2018.

[10] C. Vikasari., "Modernisasi Teknologi Realtime pada Pelelangan Ikan dalam Menumbuhkan Perekonomian Berbasis Kemaritiman," JUITA J. Inform., 2018. 